\title{
Comparison of fattening performance and slaughter value of local Hungarian cattle breeds to international breeds
}

\author{
Gabriella Holló', Karin Nuernberg², Tamás Somogyi', István Anton³ and István Holló' \\ 'Faculty of Animal Science, Kaposvár University, Kaposvár, Hungary, ${ }^{2}$ Leibniz Institute for Farm Animal Biology (FBN), \\ Dummerstorf, Germany, ${ }^{3}$ Research Institute for Animal Breeding and Nutrition, Herceghalom, Hungary
}

\begin{abstract}
The objective of the trial is to compare fattening performance, slaughter results and meat quality of bulls from international cattle breeds with local Hungarian breeds fattened under the same conditions. Altogether 62 growing bulls - Angus, Charolais, Holstein, Hungarian Grey, Hungarian Simmental, Charolais $\times$ Hungarian Grey - were fattened in small groups. The daily gain varied from 897 (Hungarian Grey) to $1240 \mathrm{~g} /$ day (Angus). In general, the lower gain value is caused by the semi-intensive fattening system with low concentrate supplementation. The slaughter weight showed a similar tendency as final weight, there was a significant difference between Angus and Hungarian Grey. The killing out of Charolais (59.50\%), Angus (56.80\%) and Hungarian Simmental (57.84\%) was significantly higher than Hungarian Grey (55.13\%) and Holstein (55.03\%). Due to Charolais crossing the dressing percentage of Hungarian Grey was developed by about $1.5 \%$.

The EU conformation scores of Charolais (9.50) and Hungarian Simmental (9.33) and the fatness scores of Angus (8.33) and Charolais $\times$ Hungarian Grey (7.33) were significantly higher than that of the other genotypes. The tissue composition of dissected carcass as well as ribs joint composition determined by $\mathrm{X}$-ray computerised tomography method showed the lean meat of Hungarian Simmental and bone proportions of Holstein to be the highest, whilst Angus had the highest fat content. Charolais und Hungarian Simmental had significant higher longissimus muscle area in ribs joint compared to Angus, Holstein and Charolais $\times$ Hungarian Grey. Angus and Hungarian Grey had the highest intramuscular fat level of the three examined muscles.
\end{abstract}

Keywords: cattle breeds, slaughter value, beef quality, X-ray computerised tomography, intramuscular fat

\section{Introduction}

The slaughter cattle/beef production of Hungary has always been an export oriented branch. This is still true at present, because the necessary conditions and biological base of beef cattle breeding are available. However, over the last decades the breed and type composition of the Hungarian cattle sector has changed considerably. During the specialization process which began in the early 1970s the world leading dairy and beef breeds and the genetic values of them were established. Due to Holstein breed, the dairy specialisation caused a spectacular milk yield growth. Now more than $68 \%$ of our cows belong to dairy breeds, whilst the percentage 
of the former dominant breed, Hungarian Simmental decreased to $15-18 \%$. Several foreign beef breeds (Hereford, Angus, Limousine, Charolais, Blonde d'Aquitaine, Blue Belgian) played a part in the establishment and improvement of Hungarian beef cattle breeding.

The accession to the EU created a new situation. The system of subsidies for fattening for high slaughter weight was changed favourably as a consequence of EU-subsidies (special premium for male cattle and slaughter premium). Besides this it is a general tendency that there is a growing interest in the traditional native animal breeds (Biedermann et al. 2009, Manatrinon et al. 2009). The exact knowledge of the performance of traditional cattle breeds is needed for the effective product output and is required for the elaboration of conscious breeding strategies.

In Hungary there are two traditional cattle breeds; one of them is Hungarian Grey cattle and the other one is Hungarian Simmental. The origin of Hungarian Grey cattle is still not definitely explored. In recent years, some publications have dealt with the production traits of this breed (Holló et al. 2004, Manatrinon et al. 2009). Hungarian Grey is very good in several traits such as longevity, health, robustness as well as easy calving but it is a late maturing breed and according to some data they have low gain performance. According to recently published data, a great valuable trait of this breed is the excellent compensation ability, which manifests itself mainly under extensive conditions (Nagy et al. 2007). Little information is available on the performance and slaughter value of purebred Hungarian Grey bulls compared to crossbred ones (Bölcskey et al. 2001). Hungarian Simmental was developed from the crossing of local breed (mainly Hungarian Grey) and the Swiss cattle at the end of the 19th century. The dual purposed Hungarian Simmental breed plays an important role for high quality beef production of Hungary due to their excellent gain, conformation and meat quality characteristics (Holló et al. 2008).

The objective of this study was to compare and to evaluate the performance of international cattle breeds (Angus, Charolais, Holstein) with local breeds (Hungarian Simmental, Hungarian Grey) as well as with their crossbred (Charolais $\times$ Hungarian Grey) in terms of fattening performance, slaughter value and meat quality including intramuscular fat level.

\section{Material and methods}

Sixty two Angus $(n=9)$, Charolais $(n=8)$, Holstein $(n=11)$, Hungarian Grey $(n=10)$, Hungarian Simmental $(n=15)$ purebred, and Charolais $\times$ Hungarian Grey $(n=9)$ crossbred young bulls were included in the experiment. The animals were loose-housed in pens with straw bedding at the Experimental farm of Kaposvár University, Hungary. Each breed group was fed with ad libitum maize silage, hay and concentrate. As the live weight of animals increased during the fattening period the portion of hay and concentrate was adjusted on the basis of chemical analysis of collected samples of the diet ingredients (Table 1).

In the finishing period (2nd period of fattening), when animals achieved $450 \mathrm{~kg}$ live weight, the concentrate contained $25 \%$ linseed supplementation. Table 2 shows the daily dry matter intake and net energy for gain $\left(\mathrm{NE}_{\mathrm{g}}\right)$ and net energy for maintenance $\left(\mathrm{NE}_{\mathrm{m}}\right)$ per breeds. The dry matter intake and net energy for gain and net energy for maintenance was measured on a group basis. Total dry matter intake varied from $10.99 \mathrm{~kg} /$ day to $11.94 \mathrm{~kg} /$ day. It was greater for Charolais than for the Holstein group. 
Table 1

The chemical and mineral composition of feedstuffs

\begin{tabular}{lcccc}
\hline & Maize silage & Grass hay & Concentrate & Concentrate with linseed \\
\hline Dry matter, \% & 33.9 & 92.5 & 88.8 & 88.5 \\
Crude protein, \% & 4.1 & 7.5 & 11.2 & 11.5 \\
Crude fat, \% & 1.1 & 1.3 & 14.9 & 15.4 \\
Crude fiber, $\%$ & 8.9 & 33.9 & 4.1 & 11.1 \\
Crude ash, $\%$ & 3.7 & 6.1 & 12.4 & 12.2 \\
Calcium, $/ \mathrm{kg}$ & 2.2 & 3.7 & 4.6 & 5.8 \\
Phosphorous, g/kg & 1.1 & 1.8 & 4.5 & 5.5 \\
Magnesium, $/ \mathrm{kg}$ & 0.8 & 1.4 & 3.5 & 3.57 \\
Potassium, g/kg & 4.4 & 9.4 & 9.1 & 6.3 \\
Sodium, g/kg & 0.2 & 0.4 & 4.8 & 5.9 \\
Manganese, $\mathrm{mg} / \mathrm{kg}$ & 27.9 & 83.7 & 152.6 & 197.6 \\
Copper, $\mathrm{mg} / \mathrm{kg}$ & 2.0 & 4.8 & 37.3 & 47.2 \\
Zinc, $\mathrm{mg} / \mathrm{kg}$ & 11.6 & 17.7 & 213.0 & 509.0 \\
Iron, $\mathrm{mg} / \mathrm{kg}$ & 509.5 & 472.0 & 240.0 & 283.0 \\
A Vitamin Ul & - & - & 37500 & 37500 \\
B12 Vitamin Ul & - & - & 5000 & 5000 \\
E Vitamin Ul & - & - & 125 & 125 \\
\hline
\end{tabular}

Table 2

The daily dry matter intake and netto energy for gain $\left(\mathrm{NE}_{\mathrm{g}}\right)$ and net energy for maintenance $\left(\mathrm{NE}_{\mathrm{m}}\right)$ per breed

\begin{tabular}{lcccccc}
\hline Item & $\mathrm{A}$ & $\mathrm{CH}$ & $\mathrm{H}$ & $\mathrm{HG}$ & $\mathrm{HS}$ & $\mathrm{CH} \times \mathrm{HG}$ \\
\hline Dry matter, kg/day & 11.91 & 11.94 & 10.99 & 11.18 & 11.65 & 11.47 \\
$\mathrm{NE}_{\mathrm{m}}$ & 73.56 & 74.20 & 69.30 & 70.33 & 72.54 & 71.53 \\
$\mathrm{NE}_{\mathrm{g}}$ & 44.24 & 44.76 & 42.11 & 42.70 & 44.10 & 43.23 \\
\hline
\end{tabular}

Each month all of the animals were weighed and daily live weight gain was calculated. The target slaughter weight was set at $600 \mathrm{~kg}$. The final live weight was measured before transportation on the day of slaughter (duration of transport $=2 \mathrm{~h}$ ), whilst the slaughter weight was detected at slaughterhouse prior to slaughter. The animals were slaughtered after $4 \mathrm{~h}$ of the arrival to slaughterhouse, at a commercial abattoir according to Hungarian Standard. At slaughter, the bulls were stunned with a captive bolt gun and killed by exsanguination. The carcasses were assessed by trained operators for conformation (an 18 point scale: 1 - poorest to 18 - best) and fatness (a 15 point scale: 1 - leanest to 15 - fattest) according to EU beef carcass classification scheme with the use of subclasses. The following traits were recorded at slaughter: slaughter weight, warm carcass weight, fat depot (kidney) and EU classification data. After $24 \mathrm{~h}$ chilling cold carcass weights were recorded and the right half carcasses were dissected into lean meat, fat, bone, and tendon. Before dressing ribs joint was removed from right half carcasses from $\mathrm{m}$. longissimus lumborum et thoracis were cut between the 11-13th ribs and weights were taken. Ribs joints were wrapped in foil and stored at $4{ }^{\circ} \mathrm{C}$ degrees until $X$-ray computer tomography analysis.

$\mathrm{X}$-ray Computer Tomography (CT) analysis of ribs joint was made by Somatom Emotion 6 (Siemens, Munich, Germany) at the Institute of Diagnostic Imaging and Radiation Oncology of the Kaposvár University. Depending on the size of rib joint 11-18 overlapping cross sectional scans (slice thickness: $8 \mathrm{~mm}$ ) were taken. The CT scan taken was actually a 
$512 \times 512$ matrix of which each element, the pixels characterized X-ray density value on the Hounsfield scale. Scans were evaluated by medical image processing (MIP) software (Kaposvár University, Kaposvár, Hungary) software. Tissues were differentiated according to the threshold values described previous by Holló et al. (2007) as follows: fat, muscle, bone, connective tissue. From the data the areas and proportion of muscle, fat and bone tissue were calculated between 11-13th ribs (3-rib cut) moreover the average area of longissimus muscle in whole ribs joint as well as at 12th rib was determinated on CT scans. The intramuscular fat level of longissimus muscle in the whole ribs joint was evaluated based on standard CT thresholds for fat on Hounsfield scale (interval 0- -200). To evaluate the intramuscular fat level a sample cut of longissimus thoracis muscle from 13th rib section, from semitendinosus muscle and psoas major muscle was taken. The Soxhlet analysis was made at the Analytical Laboratory of the Kaposvár University.

Data were analysed using SPSS 10.0 (SPSS Inc., Chicago, USA) statistical procedure. Data are expressed as mean values and standard deviations. Differences between breed group means were tested by Tukey's methods (a level of significance set at $5 \%$ ).

\section{Results and discussion}

\section{Fattening results}

Table 3 shows the main fattening performance traits. The average initial live weight and age were $262 \mathrm{~kg}$ and 307 days, respectively. The Hungarian Grey purebred and crossbred bulls started the experiment at a significant older age than other breed groups but at the comparable initial live weight.

At the beginning of linseed supplemented finishing period the average live weight was $450 \mathrm{~kg}$, among breeds there were no significant differences. It is clearly understood that the Hungarian Grey bulls were the oldest (790 days) whilst their Angus counterparts the youngest (585.1 days) at the end of fattening period.The duration of the entire fattening experimental period was 350 days, and within this the length of linseed supplemented period took 163 days. There were no differences among groups in this respect. However, Angus bulls as early maturing breed reached the slaughter weight at a significantly younger age than the late maturing Hungarian Grey bulls, consequently the fattening period of Hungarian Grey was 80 days longer compared to other genotype. During the entire experiment the rank was the following in terms of daily gain: Angus (1 $240 \mathrm{~g} /$ day), Charolais (1 126 g/day), Charolais $\times$ Hungarian Grey (1 124 g/day), Hungarian Simmental (1 041 g/day), Holstein (982 g/ day) and Hungarian Grey ( $895 \mathrm{~g} /$ day). The Angus bulls gained $113 \mathrm{~g}$ more than Charolais, besides this the daily gain of Charolais $\times$ Hungarian Grey did not differ from Angus bulls (1 148 g/day). Previously Chambaz et al. (2003) and Török et al. (2009) confirmed that Angus had similar growth rate to Charolais and Simmental breeds. Bartoň et al. (2007a) reported similar daily gain for Czech Fleckvieh (1356 g/day) and Charolais (1441 g/day). At the same time German Simmental reached the slaughter weight of $620 \mathrm{~kg}$ at a significantly younger age than the German Holstein bulls (Dannenberger et al. 2006). Lower relative growth rate was recorded in Holstein Friesian than Hungarian Grey bulls under extensive feeding system (Holló et al. 2004). In present study the lower live weight gain values of breeds can be regarded as a consequence of semi intensive fattening system with the usage of low concentrate diet. 

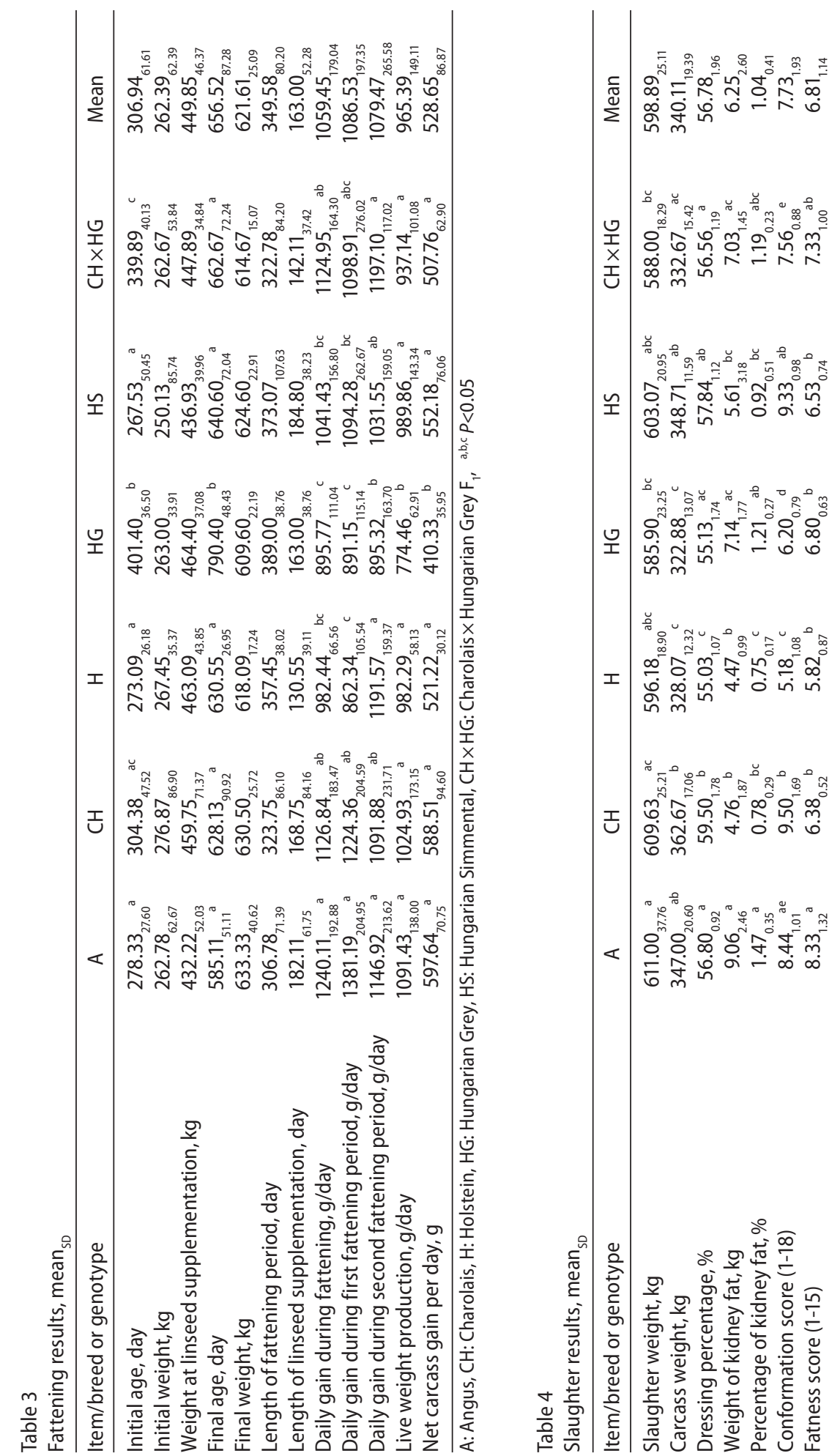

全 它 노 in $\tilde{m}$ in $\breve{\circ}$

工 $\infty_{0}^{\infty}$ นึ I

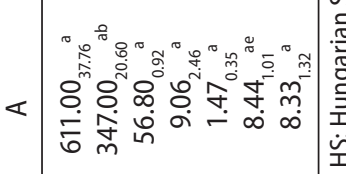

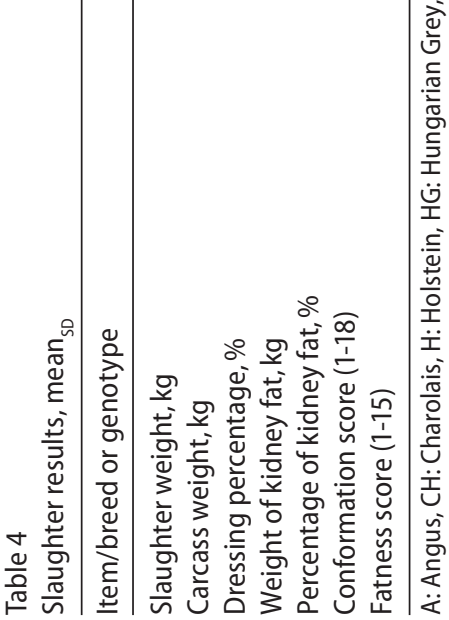


In the first fattening period Angus ( $1381 \mathrm{~g} /$ day), Charolais (1 $224 \mathrm{~g} /$ day), Charolais $\times$ Hungarian Grey $(1099 \mathrm{~g} /$ day) had higher live weight gains, on the other hand over the second linseed supplemented period only Hungarian Grey (891 g/day) had lower one compared to average gain. Comparing Angus and Holstein bulls, in spite of the same conditions there were some differences in the live weight gain. In the first fattening period Holstein had the lowest gain rate among genotypes, but in the linseed supplemented period the daily gain for Holstein ( $1190 \mathrm{~g} /$ day) was higher than for Angus (1147 g/day) bulls, as a consequence the length of linseed supplemented period for Holstein was about 50 days shorter than that of Angus and Hungarian Simmental bulls. The live weight gain of genotypes did not change by linseed supplementation except for Holstein. Similar results were reported by Bartoň et al. (2007b), Razminowicz et al. (2008) Zahrádková et al. (2010).

\section{Slaughter results}

The traits recorded at slaughter are presented in Table 4. The slaughter weight showed a similar tendency as final live weight, there was a significant difference between the breed groups of Angus and Hungarian Grey. The hot carcass weight of Charolais bulls was the highest $(362.67 \mathrm{~kg})$, whilst the lowest one was that of purebred Hungarian Grey $(322.88 \mathrm{~kg})$. The weight of hot carcass of Hungarian Grey, Holstein and Charolais $\times$ Hungarian Grey were significantly lower than that of Charolais. The killing out of Charolais (59.50\%), Angus $(56.80 \%)$ and Hungarian Simmental (57.84\%) was significantly higher than Hungarian Grey $(55.13 \%)$ and Holstein $(55.03 \%)$. These results are little bit lower than findings of Török et al. (2009) who reported $57.6 \%$ for Angus, $58.3 \%$ for Hungarian Simmental and $60 \%$ for Charolais bulls. Due to Charolais crossing the dressing percentage of Hungarian Grey was developed by about $1.5 \%$.

The amount and percentage of kidney fat was the highest for Angus (9.06 kg and $1.47 \%)$, whereas the lowest one was measured for Holstein bulls ( $4.47 \mathrm{~kg}$ and $0.75 \%)$. The low percentage of kidney fat of Charolais bulls confirmed that the higher fat incorporation into the body at this slaughter weight has been not yet commenced. Similar explanation was given by Zahrádková et al. (2010), results showed that Charolais heifers had lower degree of fatness compared to Limousine counterparts. The kidney fat of crossbred and purebred Hungarian Grey did not differ significantly compared to Angus bulls. According to EU classification results the Charolais (9.50) and Hungarian Simmental (9.33) bulls had higher conformation score than the other genotypes. Based on conformation scores it can be concluded that Charolais and Hungarian Simmental were classified as U- and R+, followed by Angus bulls characteristic category of which was Ro.

Similarly to our findings Bartoň et al. (2006) reported a significantly better conformation for Charolais bulls in comparison with the other breeds. However, they found significant differences between Charolais and Simmental in EU conformation score.The effect of Charolais crossing was expressed also in conformation classes because crossbred Hungarian Grey belonged mainly to R- contrary to purebred Hungarian Grey which received a lower score for conformation $(\mathrm{O}+)$. As a dairy type, Holstein bulls received the lowest conformation score $(5,18=0)$. Similar conformation class was reported by Polgár et al. (2005) and Szabó et al. (2008) for Angus bulls. Harangi \& Béri (2009) found a higher conformation score for 
Charolais and in the study by Bene et al. (2009) and Polgár (2007) a lower conformation score was reported for Hungarian Simmental in contrast with our results.

As expected, Angus bulls received the highest fat score (8.33), which was significantly higher than the value of other genotypes (Link et al. 2007, Török et al. 2009). Holstein bulls had the lowest fat score (5.82). The lower fat score of Charolais bulls (6.38) can be explained with the fact that a higher slaughter weight can be achieved without more intensive fat incorporation in this breed (Chambaz et al. 2003). Contrary to previous data (Enyedi \& Kovácz 1990, Bozó 1993) in our study Hungarian Grey and Charolais $\times$ Hungarian Grey bulls had higher fat score. The fat score of Angus and Hungarian Simmental are in line with the findings of Bene et al. (2009) and Polgár et al. (2005).

\section{Dressing results}

Table 5 shows the main cutting results. Charolais had the highest cold carcass weight ( $355.03 \mathrm{~kg}$ ) and Hungarian Grey, Holstein and Charolais $\times$ Hungarian Grey the lowest one. Cold carcass weight for Angus $(339.79 \mathrm{~kg}$ ) and Hungarian Simmental $(341.11 \mathrm{~kg})$ did not differ significantly. The average cooling shrinkage was $2 \%$, the highest value was measured in Holstein, but Hungarian Grey had the lowest one, although the differences were not significant. The values of carcass are determined by tissue composition. Among different genotypes there were significant differences for all tissues except for tendon. The amount of lean meat of Charolais and Hungarian Simmental significantly exceeded that of other breeds. At the same time the lean meat of Angus $(112.63 \mathrm{~kg})$, Holstein $(113.24 \mathrm{~kg})$, Hungarian Grey $(112.74 \mathrm{~kg})$ as well as Charolais $\times$ Hungarian Grey $(115.44 \mathrm{~kg})$ did not differ significantly. Comparing to EU conformation classes, breeds with a higher conformation score have a higher lean meat content in carcass. Piedrafita et al. (2003) concluded similar findings in their study.

As for fat in carcass the order of breeds was the following: Angus $(21.08 \mathrm{~kg})$, Charolais $\times$ Hungarian Grey $(12.83 \mathrm{~kg})$, Hungarian Grey $(11.91 \mathrm{~kg})$ Charolais $(10.08 \mathrm{~kg})$, Hungarian Simmental $(9.21 \mathrm{~kg})$ and Holstein $(8.22 \mathrm{~kg})$. Holstein $(33.20 \mathrm{~kg})$ and Charolais $(32.74 \mathrm{~kg})$ had the highest bone contents.

As for the percentage of lean meat, values above $70 \%$ were recorded except for Angus bulls, they ranged from $66.69 \%$ (Angus) to $73.99 \%$ (Hungarian Simmental). With respect to fat amount, the fat percentage of carcass was the highest in Angus bulls (12\%), which is twice as high as that of Hungarian Simmental (5\%), Holstein (5\%) and Charolais (6\%) bulls. For Hungarian Grey purebred and crossbred bulls the bone percentage was $18 \%$. Concerning bone proportion only Holstein group $(21 \%)$ differed significantly from the values of Hungarian Simmental, Hungarian Grey, Charolais $\times$ Hungarian Grey $(18 \%)$ and Charolais (19\%) bulls. In our previous study (Holló et al. 2004) the bone content of Holstein varied from 21 to $23 \%$, depending on the diet. Hungarian Simmental bulls showed the most prosperous lean and fat proportion, whilst lean and bone ratio varied from 3.42 (Holstein) to 4.22 (Hungarian Simmental). Hungarian Grey and Charolais $\times$ Hungarain Grey had 4.02 and 4.01. The lean meat production proves the superiority of Charolais and Hungarian Simmental, on the other hand the lowest value can be observed in Hungarian Grey.

The effects of genotype on rib joint composition and area as well as fat content of longissimus muscle are shown in Table 6. 


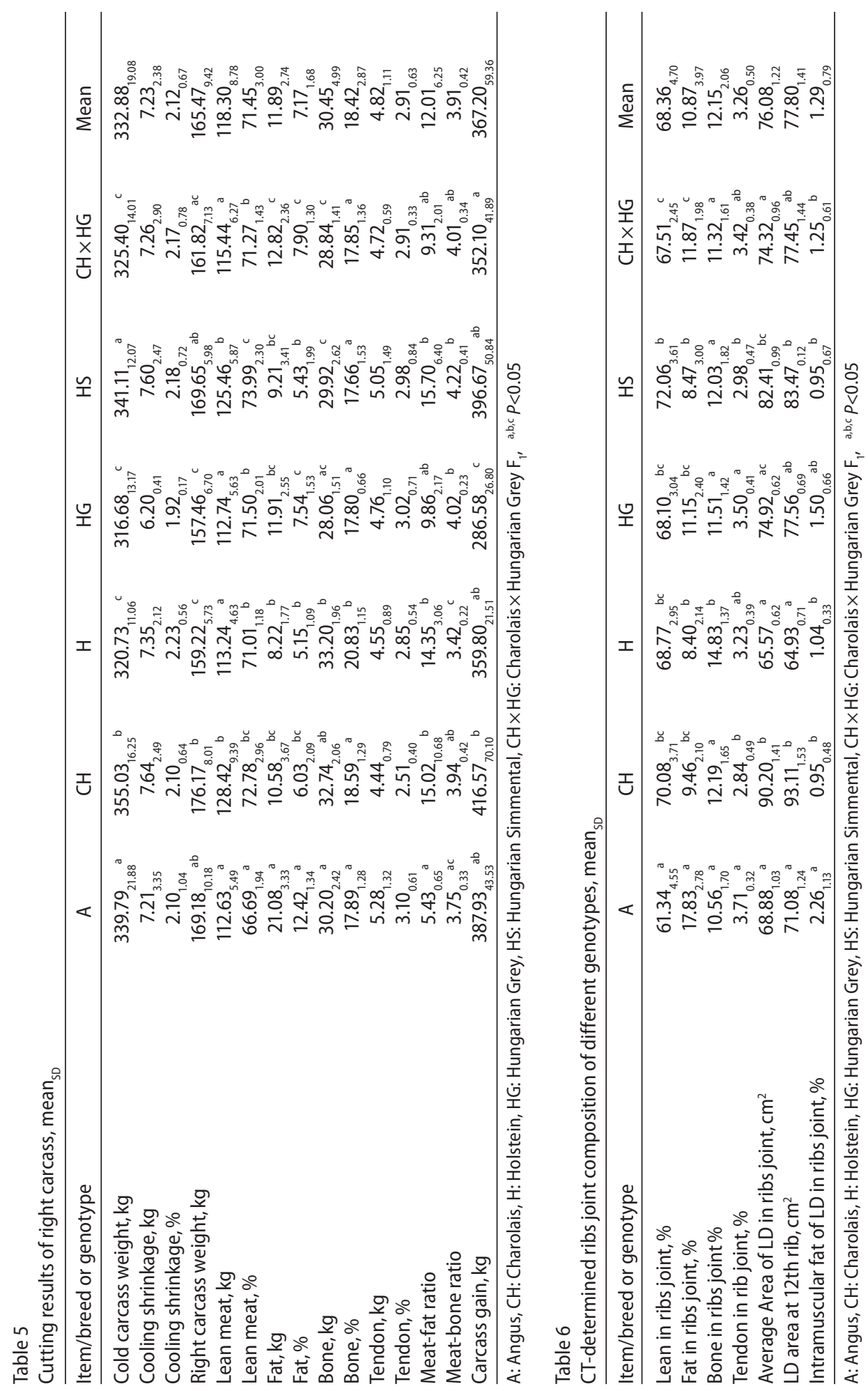


The tissue composition of ribs joint determined with CT was significantly affected by genotype. Muscle proportion was significantly higher and fat proportion and intramuscular fat content of longissimus muscle were lower for Hungarian Simmental than Angus. The bone percentage in rib joint was the highest for Holstein and differed significantly to other genotypes. Charolais and Hungarian Simmental had the lowest tendon percentage in ribs joint. Significantly higher percentages were measured in ribs joint by CT for Angus and Hungarian Grey bulls. The tissue composition of ribs joint determined by using CTexamination showed the same tendency as the carcass composition of genotypes. The average area of longissimus muscle in ribs joint was lower $\left(76 \mathrm{~cm}^{2}\right)$ than the area of longissimus muscle at the 12th rib $\left(78 \mathrm{~cm}^{2}\right)$. Charolais and Hungarian Simmental had significantly higher longissimus muscle area in ribs joint than Angus, Holstein, and Charolais $\times$ Hungarian Grey crossbred counterparts. Previously, Pfuhl et al. (2007) reported differences in cross sectional area of longissimus muscle between Charolais and Holstein bulls.The longissimus muscle area at the 12th rib was significantly lower for Angus and Holstein compared to other genotypes. Török et al. (2009) measured via ultrasonic measurements higher ribeye area for Charolais, Angus and Hungarian Simmental bulls than our values. Our measurements were made after dissection at $24 \mathrm{~h}$ post mortem, whilst Török et al. (2009) measured carcass ribeye area immediately after slaughter.

\section{Intramuscular fat content}

The intramuscular fat level is one of the most important meat quality traits mostly affecting the eating quality of beef. The differences of fat level in beef can be regarded as the effect of breed or genotype (Scollan et al. 2006, Šubrt et al. 2006) because the beef from late maturing breeds (Blue Belgian, Limousine) have lower level of intramuscular fat than early maturing breeds (Angus, Japanese Black). In addition to age, weight and gender of animals as well as muscle type also affected intramuscular fat content. From extrinsic factors the most important ones are nutrition, and intensity of fattening, because intensive and high concentrate diet caused a higher degree of fat level. The minimum amount of intramuscular fat to achieve acceptable consumer satisfaction is about $3 \%$ to $4 \%$ for beef (Hocquette et al. 2010). The intramuscular fat level of longissimus muscle was determined both by CT-procedure (Table 6) and Soxhletmethod (Table 7). Based on results it can be established that the intramuscular fat percentage measured by CT is generally lower compared to values of the other method. According to both methods the rank order of genotype concerning intramuscular fat level is the same for the first three cases (Angus, Hungarian Grey purebred and crossbred). In the rank order of the other three changes can be explained by high variability in the distribution of intramuscular fat percentage along the longissimus muscle. The CT-measured fat percentage of longissimus muscle was determinated in whole ribs joint, whilst chemically measured fat level was analysed only at 13th rib. In spite of this, the correlation between methods was $r=0.49$.

Among genotypes significant differences were detected, moreover the effect of muscle was also significant on intramuscular fat content (Table 7). The intramuscular fat level of muscles ranged from 1.8 ( $\mathrm{m}$. semitendinosus) to 3.6 ( $\mathrm{m}$. psoas major). The beef from Angus bulls contained more intramuscular fat than other genotypes except for Hungarian Grey. The intramuscular fat content of longissimus muscle of Angus bulls was higher than previously 
published by Cuvelier et al. (2006). The average intramuscular fat content (3.45\%, and 3.08\%) of beef from purebred and crossbred Hungarian Grey exceeded the results of Bölcskey et al. (2001). This proved our previous opinion (Holló et al. 2005) namely, the view claiming that the beef of Hungarian Grey does not contain enough intramuscular fat hence it is too firm, needs to be reconsidered.

Table 7

Intramuscular fat content (\%) of longissimus thoracis, semitendinosus and psoas major muscle, mean $_{\mathrm{SD}}$

\begin{tabular}{|c|c|c|c|c|c|c|c|}
\hline Item/breed or genotype & A & $\mathrm{CH}$ & $\mathrm{H}$ & HG & HS & $\mathrm{CH} \times \mathrm{HG}$ & Mean \\
\hline M. longissimus thoracis & $4.42_{1.96}{ }^{a}$ & $1.85_{0.71}^{b}$ & $2.27_{1.21^{b}}$ & $3.45_{1.73}^{\text {ac }}$ & $2.41_{1.55}^{b c}$ & $3.08_{0.89}^{b c}$ & $2.87_{1.60}$ \\
\hline M. semitendinosus & $2.11_{0.78}^{a}$ & $1.58_{0.50} \mathrm{ab}$ & $1.15_{0.37}^{1.21} \mathrm{~b}$ & $2.15_{0.79}{ }^{a}$ & $1.62_{0.82}^{1.33}$ & $2.17_{0.46^{a}}^{0.89}$ & $1.77_{0.74}^{1.00}$ \\
\hline M. psoas major & $4.74_{1.36}{ }^{a}$ & $3.56_{1.89}^{0.50} a b c$ & $2.91_{0.81}^{0.37}$ & $4.60_{1.66}{ }^{a}$ & $2.61_{1.30}^{0.82}{ }^{c}$ & $3.91_{1.04}^{0.46}$ & $3.60_{1.55}^{0 . / 4}$ \\
\hline Mean & $3.76_{1.83}^{1.36}$ & $2.33_{1.46}$ & $2.11_{1.12}$ & $3.40_{1.74}$ & $2.21_{1.30}$ & $3.05_{1.08}$ & $2.75_{1.55}$ \\
\hline
\end{tabular}

A: Angus, CH: Charolais, H: Holstein, HG: Hungarian Grey, HS: Hungarian Simmental, $\mathrm{CH} \times \mathrm{HG}$ : Charolais $\times$ Hungarian Grey $\mathrm{F}_{1}, \mathrm{a}, \mathrm{b}, \mathrm{c} P<0.05$

Szabó et al. (2002), Holló et al. (2005) and Mach et al. (2006) reported values from 1.34 to $2.95 \%$ for the fat content in longissimus muscle of Holstein bulls according to the intensity level of diet. In our study Holstein bulls had $2.27 \%$ of intramuscular fat. It did not differ from the lowest intramuscular fat level which was measured in Charolais bulls. The intramuscular fat level of longissimus thoracis muscle of Hungarian Simmental is significantly higher than that of Charolais and Holstein bulls, but lower compared to Angus bulls.

Among muscles, semitendinosus muscle had the lowest level of intramuscular fat. Similar to longissimus thoracis muscle, the semitendinosus muscle of Angus (2.11\%), Hungarian Grey $(2.15 \%)$ Charolais $\times$ Hungarian Grey $(2.17 \%)$ contained more intramuscular fat, whereas Holstein had the lowest one (1.15\%). The intramuscular fat level in semitendinosus muscle of Charolais (1.58) and Hungarian Simmental (1.62) differed from breeds. Psoas major muscle of Angus (4.74\%), Hungarian Grey (4.60\%), and Charolais $\times$ Hungarian Grey (3.91\%) deposited the highest intramuscular fat level. At the same time the intramuscular fat level of psoas major muscle of Hungarian Simmental is significantly lower (2.61\%) moreover it was exceeded by Holstein (2.91\%) and Charolais (3.56\%).

In conclusion, significant breed differences were observed in growth performance, slaughter value and carcass traits.

Compared to international breeds (Angus, Charolais) Hungarian Simmental had the highest meat yield and the most prosperous meat-fat and meat-bone ratio of carcass, however under semi intensive fattening condition the breed could achieve a lower live weight gain in comparison with Angus.

Hungarian Grey had similar growth rate as dairy breeds (Holstein), but at similar carcass weight Hungarian Grey accumulated more fat and had lower bone proportion than Holstein. Due to Charolais crossing the daily gain, carcass gain and dressing percentage as well as EU conformation score of crossbred animals were improved. The intramuscular fat level of muscles in Hungarian Grey was similar to Angus bulls.

The longissimus muscle area of Hungarian local breeds was relatively smaller than in Charolais but bigger than in Angus and in Holstein breeds measured results. 


\section{Acknowledgement}

This experiment was founded by the Hungarian Scientific Research Fund (OTKA CK 78289).

\section{References}

Bartoň L, Kudrna V, Bureš D, Zahrádková R, Teslík V (2007a) Performance and carcass quality of Czeh Fleckvieh, Charolais and Charolais $\times$ Czeh Fleckvieh bulls fed diets based on different types of silages. Czech J Anim Sci 52, 269-276

Bartoň L, Marounek M, Kudrna V Bureš D, Zahrádková, R (2007b) Growth performance and fatty acid profiles of intramuscular and subcutaneous fat from Limousin and Charolais heifers fed extruded linseed. Meat Sci 76, 517-523

Bartoň L, Řehák D, Teslík V, Bureš D, Zahrádková R (2006) Effect of breed on growth performance and carcass composition of Aberdeen Angus, Charolais, Hereford and Simmental bulls. Czech J Anim Sci 51, 47-53

Bene Sz, Fekete Zs, Fördős A, Füller I, Kiss B, Rádli A, Török M, Wagenhoffer Zs, Polgár JP, Szabó F (2009) [Growth, carcass value and meat quality of purebreed and crossbreed young fattening bulls and heifers. 1st paper: fattening and slaughtering results]. Anim Breed Feed 58, 23-40 [in Hungarian]

Biedermann G, Hecht W, Fandrey E, Holstein R, Frölich K (2009) Population genetic analysis of White Park Cattle in Germany. Arch Tierz 52, 561-573

Bozó S (1993) [The evaluation of meat production of local Hungarian breeds]. Állattenyésztés és Takarmányozás 42, 3-14 [in Hungarian]

Bölcskey K, Bárány I, Berta E, Bíró G, Bodó I, Bozó S, Györkös I, Lugasi A, Süth M, Székely-Körmöczy P, Szita G, Sárdi J (2001) [Terminal crossing of Hungarian Grey cows by Belgian White Blue and Charolais breeds]. Állattenyésztés és Takarmányozás 50, 43-57 [in Hungarian]

Chambaz A, Scheeder MRL, Kreuzer M, Dufey PA (2003) Meat quality of Angus, Simmental, Charolais and Limousin steers compared at the same intramuscular fat content. Meat Sci 63, 491-500

Cuvelier C, Clinquart A, Hocquette JF, Cabaraux JF, Dufrasne I, Istasse L, Hornick JL (2006) Comparison of composition and quality traits of meat from young finishing bulls from Belgian Blue, Limousin and Aberdeen Angus breeds. Meat Sci 74, 522-531

Dannenberger D, Nuernberg K, Nuernberg G, Ender K (2006) Carcass- and meat quality of pasture vs concentrate fed German Simmental and German Holstein bulls. Arch Tierz 49, 315-328

EnyediS, Kovács I (1990) [Slaughter values of Hungarian Grey growing bulls of different breeding combinations]. Állattenyésztés és Takarmányozás 39, 311-320 [in Hungarian]

Harangi S, Béri B (2009) [Slaughter results of Charolais bulls]. Magyar Mezőgazdaság 14, 9 [in Hungarian]

Hocquette JF, Gondret F, Baéza E, Médale F, Jurie C, Pethick DW (2010) Intramuscular fat content in meatproducing animals: development, genetic and nutritional control, and identification of putative markers. Animal 4, 303-309

Holló G, Nürnberg K, Seregi J, Holló I, Repa I, Ender K (2004) [Influence of feeding on fattening performance and carcass quality of young Hungarian Grey and Holstein Friesian bulls]. Arch Tierz 47, 313-323 [in German]

Holló G, Nuernberg K, Repa I, Holló I, Seregi J, Pohn G, Ender K (2005) [Effect of feeding on the composition of the intramuscular fat in longissimus muscle and different fatty tissues of Hungarian Grey and Holstein Friesian bulls. 1. Fatty acid profile]. Arch Tierz 48, 537-546 [in German]

Holló G, Szűcs E, Tőzsér J, Holló I, Repa I (2007) Application of X-ray Computer Tomography (CT) in Cattle Production. Asian Australas J Anim Sci 20, 1901-1909

Holló G, Nuernberg K, Ender K, Lóki K, Seregi J, Holló I (2008) Carcass characteristics and meat quality of Hungarian Simmental young bulls fed different forage to concentrate ratios with or without linseed supplementation. Arch Tierz 51, 517-530

Link G, Willeke Holstein, Golze M, Bergfeld U (2007) [Fattening- and slaughter performance of bulls and heifers of beef breeds and the cross breed German Angus × Simmental]. Arch Tierz 50, 356-362 [in German] 
Mach N, Devant M, Díaz I, Font-Furnols M, Oliver MA, García JA, Bach A (2006) Increasing the amount of n-3 fatty acid in meat from young Holstein bulls through nutrition. J Anim Sci 84, 3039-3048

Manatrinon S, Fürst-Waltl B, Baumung R (2009) Genetic parameters for calving ease, gestation length and stillbirth in three endangered Austrian blond cattle breeds. Arch Tierz 52, 553-560

Nagy B, Bene Sz, Bodó I, Gera I, Szabó F (2007) [Live weight and body measurements of Hungarian Grey bulls and cows]. Anim Breed Feed 56, 195-203 [in Hungarian]

Pfuhl R, Bellmann, O, Kühn, C, Teuscher F, Ender K, Wegner J (2007) Beef versus dairy cattle: a comparison of feed conversion, carcass composition, and meat quality. Arch Tierz 50, 59-70

Piedrafita J, Quintanilla R, Sañudo C, Olleta JL, Campo MM, Panea B, Renand G,Turin F, Jabet S, Osoro K, Oliván MC, Noval G, García P, García MD, Oliver MA, Gispert M, Serra X, Espejo M, García S, López M, Izquierdo M (2003) Carcass quality of 10 beef cattle breeds of the Southwest of Europe in their typical production systems. Livest Prod Sci 82, 1-13

Polgár JP (2007) [Fattening and slaughter performance of Hungarian Simmental young bulls]. Magyartarka 7, 16-18 [in Hungarian]

Polgár JP, Wagenhoffer ZS, Grubics ZS, Hornyák Z, Török M, Lengyel Z, Szabó F (2005) [Slaughter results and carcass traits of F1 and R1 genotyped Red Angus cattle]. Anim Breed Feed 54, 555-565 [in Hungarian]

Razminowicz RH, Kreuzer M, Leuenberger Holstein, Scheeder MRL (2008) Efficiency of extruded linseed for the finishing of grass-fed steers to counteract a decline of omega-3 fatty acids in the beef. Livest Sci 114, 150-163

Scollan N, Hocquette JF, Nuernberg K, Dannenberger D, Richardson I, Moloney A (2006) Innovations in beef production systems that enhance the nutritional and health value of beef lipids and their relationships with meat quality. Meat Sci 74, 17-33

Šubrt J, Filipčík R, Župka Z, Fialová M, Dračková E (2006) The content of polyunsaturated fatty acids in intramuscular fat of beef cattle in different breeds and crossbreds. Arch Tierz 49, 340-350

Szabó F, Fekete Zs, Fürdős A, Zsuppán Zs, Kanyar R, Török M, Polgár JP, Bene Sz (2008) [Growth and slaughter value of young fattening bulls of different genotypes fed identical feeding regimen]. Anim Breed Feed 57, 523-536 [in Hungarian]

Szabó F, Polgár JP, Farkasné Zele E, Lengyel Z, Holló I (2002) [Some new data on the slaughter results, carcass traits and chemical composition of muscles of Holstein-Friesian bulls at different ages]. Anim Breed Feed 51, 577-585 [in Hungarian]

Török M, Polgár JP, Kocsi Gy, Farkas V, Szabó F (2009) Correlation of ultrasonic measured ribeye area and fat thickness to the certain traits measured on slaughtered bulls (Short Communication). Arch Tierz 52, 23-27

Zahrádková R, Bartoň L, Bureš D, Teslík V, Kudrna V (2010) Comparison of growth performance and slaughter characteristics of Limousin and Charolais heifers. Arch Tierz 53, 520-528

Received 4 May 2011, accepted 23 August 2011.

Corresponding author:

Gabriella Holló

email: hollo.gabriella@sic.hu

Faculty of Animal Science, Kaposvár University, Guba S. 40, 7400 Kaposvár, Hungary 